\title{
Business model canvas in global enterprises
}

\author{
Branislav Micieta ${ }^{1,},{ }^{*}$ Miroslav Fusko ${ }^{1}$, Vladimira Binasova ${ }^{1}$ and Beata Furmannova ${ }^{1}$ \\ ${ }^{1}$ University of Zilina, The Faculty of Operation and Economics of Transport and Communications, \\ Univerzitna 1, 01026 Zilina, Slovak Republic
}

\begin{abstract}
Each business model is based on a particular business model, but some businesses do not have a defined model. Global megatrends are among the systemic characteristics of today's challenges. This paper deals with the proposed business model for a specific enterprise. Slovak entrepreneurs are mostly cautious and rather hesitate to accept something that is unfamiliar to them and new to them. Key enabling technologies will play a decisive role in the future competitive environment, and with them the new way to come value of products. These innovations are a prerequisite for product innovation to meet the needs, wishes and possibilities of customers. Oftentimes, they will accept it as a necessary measure when they see how the competition beats them. We could also write a similar scenario about modern business models, where most foreign companies have elaborated them in detail and set up to make the company successful in the future. The business model describes the basic principle of how an enterprise creates values, how it captures and mediates. The first section focuses on specific types of business models and their development and survey of the literature. The case study in selected company deals with the use of strategic management methods, as well as finding out the current state, from which the complex business model was created. The results showed that the implementation of the solution helps the company to achieve the goal and subsequent development.
\end{abstract}

\section{Introduction}

The success of business models cannot be separated from the mastery of certain entrepreneurial competencies required by a particular business. Business modelling is often on a very strategic level [1]. Business model and entrepreneurship are closely linked [2]. This means that entrepreneurs who have entrepreneurial competence will conduct a business model to become successful. Furthermore, several studies have shown a significant influence of individual competence on firm performance [3, 4]. Thus, entrepreneurship and business development are widely accepted as keys to building a more vibrant economy leading to national re-building [5]. Thus, successful entrepreneurs are those with competence [6].

The business model explains how each innovation can create a new market or disrupt the competitive advantage of its major competitors [7]. Indeed, competency has a direct influence more dominantly on the performance of employees compared to the function of

* Corresponding author: vladimira.binasova@fstroj.uniza.sk 
leadership and organizational culture [8], whereas valuable competence, rare, difficult to imitate, and are difficult to be replaced are all factors that become a source of company excellence in competition with other companies [9]. It also makes the competency as a force that cannot be easily imitated by competitors [10].

Based on the results of research [11], we propose a model of developing entrepreneurship competencies for successful business model canvas, as illustrated in Fig. 1.

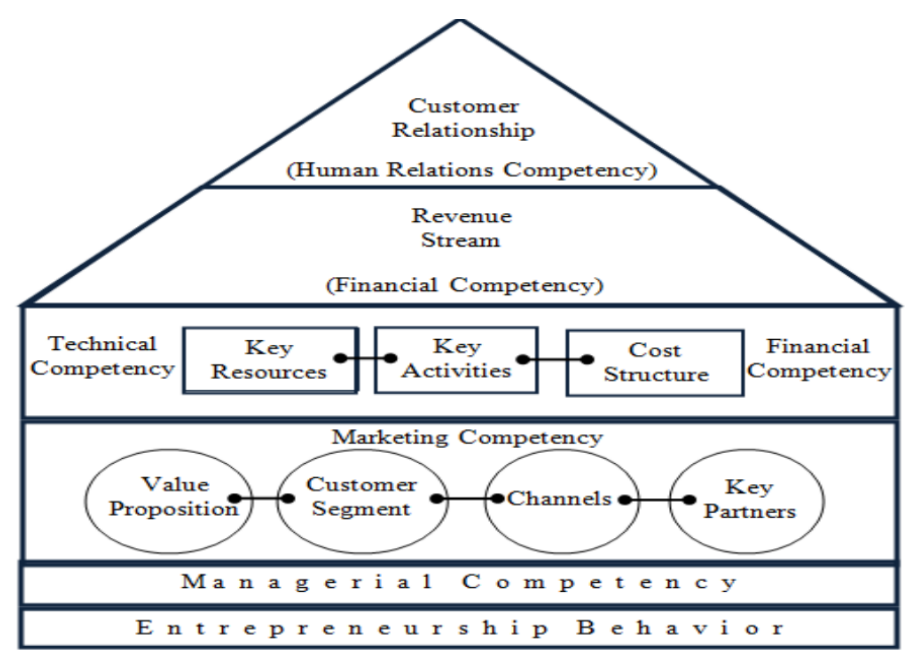

Fig. 1. Developing Entrepreneurial Competencies for Successful Business Model Canvas [11]

\section{Methodology}

SWOT analysis, analysis of the entrepreneur index and business model Canvas were used in the analysis of the current state of the company. SWOT is an acronym for Strengths, Weaknesses, Opportunities and Threats. The Strengths (S) and Weaknesses (W) are considered to be internal factors over which you have some control. The Opportunities $(\mathrm{O})$ and Threats $(\mathrm{T})$ are considered to be external factors over which you have essentially no control.

Strengths are the qualities that enable us to realise the organisation's mission. These are the basis on which continued success can be made. Examples of organisational strengths are huge financial resources, broad product line, no debt, committed employees, etc.

Weaknesses are the qualities that prevent us from accomplishing our mission and achieving our full potential. These weaknesses deteriorate organizational success and growth. Weaknesses in an organization may be obsolete machines, insufficient research and development facilities, narrow product range, poor and complicated decision-making, debts, high employee turnover, complex decision-making process, wastage of raw materials, etc.

Opportunities are presented by the environment within which our organisation operates. These arise when an organisation can take benefit of conditions in its environment to plan and realise strategies that enable it to become more profitable. Opportunities may arise from market, competition, industry/government and technology.

Threats arise when conditions in the external environment jeopardize the reliability and profitability of the organisation's business. Threats are uncontrollable. When a threat comes, stability and survival can be at stake. Examples of threats are - unrest among 
employees; permanently changing technology; increasing competition leading, price wars and reducing industry profits $[12,13]$.

To make it easier for professionals to design a business model, the Canvas business model is becoming increasingly popular, being considered the most comprehensive business model. It describes the economic aspect of the company through income and expenditure flows $[14,15]$.

It captures the places where costs and revenues are consumed and determines the value created for the customer. It allows you to explore business, formulate a business model, and also serves as a tool for innovation.

The entrepreneur index can be described as a tool to support the business environment in Slovakia. This tool is able to verify and analyze any enterprise doing business in the Slovak Republic.

\section{Case study}

The main goal of the company is sustainable development and profit. It focuses on the grocery, beverage and tobacco business that it sells through its stores, collecting cash for the sale of goods. This type of sales belongs to the retail department. Another way of selling food is by selling through wholesale.

This means that the goods are sold from the warehouse via customer orders, this sale is made via invoice sales with a maturity of 14 to 30 days. Customers are various accommodation facilities, catering establishments, other retailers or amusement parks.

Fig. 2 depicts SWOT analysis.

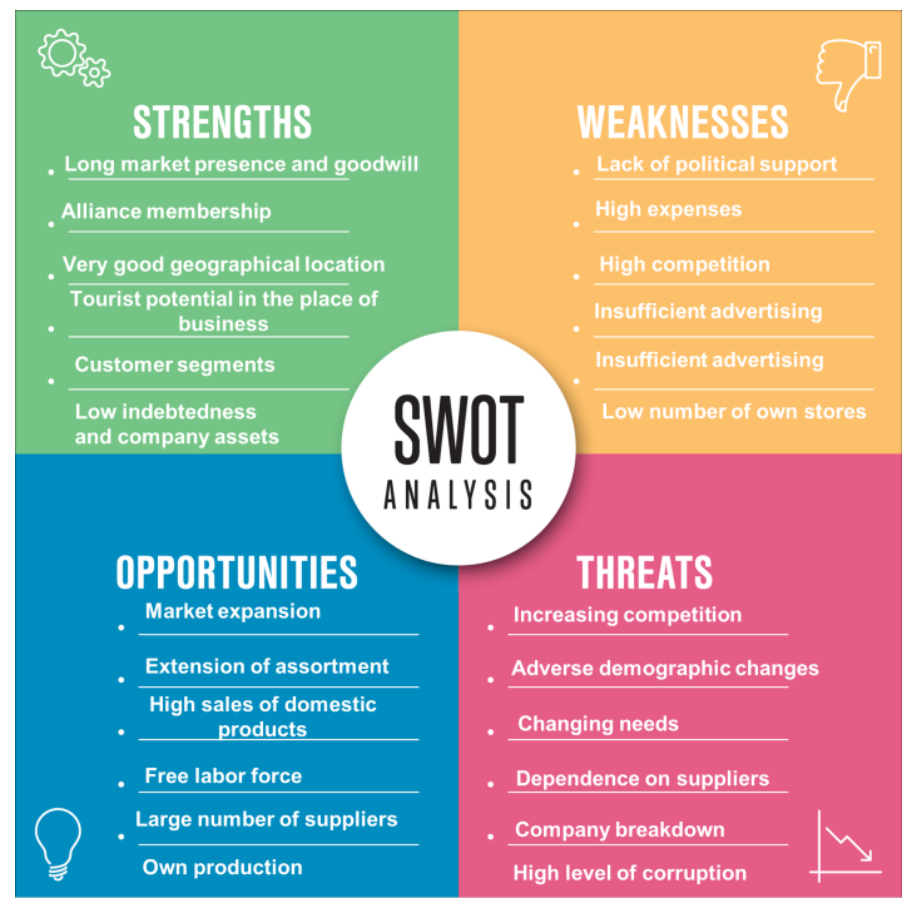

Fig. 2. SWOT analysis of selected company.

The proposed business model (Fig. 3) for a company describes its key aspects, points out potential places for improving the existing business plan, its development, but also for identifying its strengths, weaknesses, opportunities and threats. 
The business model can also be used to start a new company, but it can only serve as a starting point for doing business. [16, 17]. Every company has different requirements for business, it depends on what area and in which environment it wants to do business [18, 19].

For managers, it can serve as an inspiration and stepping stone in improving existing business models or creating new ones [20]. The business model proposal is inspired by the Canvas business model.

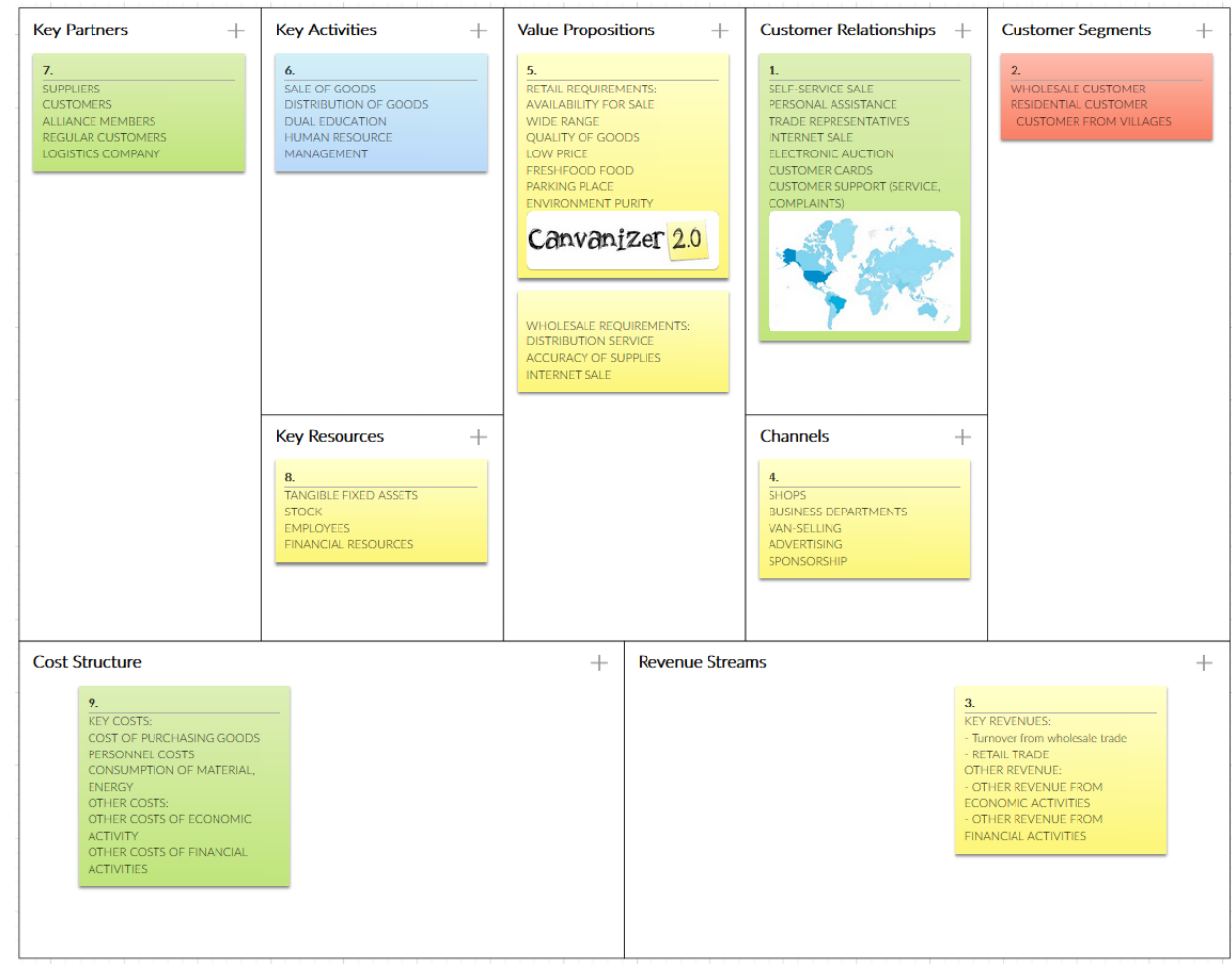

Fig. 3. Business model Canvas of selected company.

Entrepreneurs can check and get basic information about their competitors, but also about their business partners or suppliers.

The Entrepreneur Index provides a detailed view of arrears in social and health insurance or taxes, whether the business is not in bankruptcy or execution or other statements relating to the business.

This tool is publicly available and the values it provides are calculated from publicly available sources, databases and registers.

The most important outputs of the Entrepreneur Index include the financial analysis of the company and the Entrepreneur Index itself. It focuses on the most important indicators that speak about the health of society. The Entrepreneur Index evaluates 17 indicators whose values can reach a maximum of 160 points.

We have earned 12 points for the company under review. The value achieved for the company in the Entrepreneur Index is 0.7813 which is on grade A. This category calls the economic condition of the company very good. 


\section{Results and discussion}

In this section, we will discuss the above results. A positive figure suggests that strengths outweigh weaknesses as well as opportunities over threats. According to the graph from the SWOT analysis (Fig. 4), it follows that the position of the company is in the upper right quadrant, which means that the company has an ideal business environment.

It may use an offensive strategy in further planning and not be afraid to take advantage of these opportunities, as this position is likely to last in the near future.

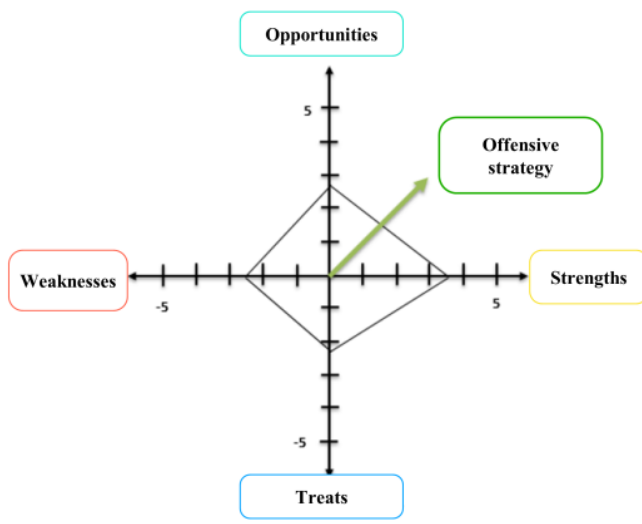

Fig. 4. Diagram of SWOT analysis results.

SWOT analysis provides a more objective view of the company's current position in the area of its business by comparing its specific internal and external factors. From the outcome, it is possible to estimate the position of the competition as the external environment is the same for the company and its competitors. For example, if a company has a weaker position than a competitor, it will be one of the strengths of a competitor, so the remaining strengths and weaknesses of the competition could be estimated.

After analyzing the internal and external aspects of the company, it emerged that the company has a very good market position and it is recommended to use an offensive strategy. This means that with the position that the company has to be afraid of competition and should start to realize opportunities. Expansion of the clientele, extension of the assortment, cooperation with domestic producers, utilization of supplying power or start of own production can have a significant benefit for the company, which will support the further development of the company in addition to increasing profit. Also, the prevailing strengths over weaknesses predetermine it for success in this activity.

The results obtained from the entrepreneur index are identical to the results of the SWOT analysis. The company achieved mark A, which indicates its economic condition as very good. The Entrepreneur Index dealt with the company in a more complex and detailed way, and the result is the greater the informative value. It depicts a promising future for companies, which means that the goals set for sustainable development and profit growth are realistic. The entrepreneur's index is publicly accessible; its good result can reach out to potential partners with whom long-term cooperation can be established.

A detailed analysis of these aspects has described the strengths and weaknesses of the company and pointed out where changes can help achieve the goals. The key aspects are closely linked and a change in one viewpoint may trigger further changes in other aspects. Changes in key partners, key activities, key activities, key resources, customer segments, distribution channels have a major impact on cost structure and revenue 
sources. Making changes requires funds that are included in costs, so you need to think carefully and consider whether the benefits outweigh these costs.

The business model is also important in the fight against the competition, a comprehensive company description will help employees and partners understand key elements in achieving the company's goal. The created business model canvas will also result in a final financial plan for the company, which will address sales, revenues, costs and expenses for 2019. The plan will be based primarily on statistics from previous years, but also on the planned changes resulting from the business model.

When creating a business model, we realized what is important for a company to be able to face competition and here are some tips on what the company should focus on in the coming years:

- focus on improving communication with key partners,

- highlighting the importance of human resources for society and their accurate appraisal,

- continuing training and education of staff,

- monitoring market changes and constantly innovating, modernizing and exploiting the latest technologies,

- increase in advertising,

- work to reduce costs.

In addition to our advice, we also have a few suggestions that relate directly to these tips:

- increase in minimum supply price, extension of the range,

- increasing the number of own operations, reducing energy consumption.

Although the main activity of the company is the sale of goods, so inseparable part is the distribution of goods to wholesale customers.

In addition to reducing logistics costs for company, there will be a number of benefits for the customer. The customer orders either a larger quantity of goods and does not have to take over the goods so often, or orders a wider range to increase their customers' satisfaction, as most wholesale customers continue to provide these to end consumers. Other benefits of fewer goods receipts are simplification of invoicing, not only a smaller number of invoices but also lower fees for payment of these invoices.

This proposal is followed by another, which consists in expanding the range. Although the company has a wide assortment, there are areas of goods that are becoming more popular and need to be brought closer to the customer. We would expand the range especially in the segment for pets.

This work was supported by the Slovak Research and Development Agency under the contract No. APVV-16-0488.

\section{References}

1. M. D., Reuver, H. Bouwman, T. Haaker, Business Model Roadmapping: A Practical Approach to Come from an Existing To A Desired Business Model. International Journal of Innovation Management 17, 1-18 (2013)

2. J. Freiling, Business model innovation- a concept between organizational renewal and industry transformation. Journal of Entrepreneurship, Management and Innovation 11, 3 (2015)

3. Y. Absah, Kompetensi: Sumberdaya Pendorong Keunggulan Bersaing Perusahaan. Jurnal Manajemen Bisnis 1, 109-116 (2008) 
4. E. Purwanto, M. S. Idrus, K. Ratnawati, Kinerja Perusahaan Terkait dengan Teknologi Informasi, Lingkungan, dan Kompetensi. Jurnal Aplikasi Manajemen 91, 901-909 (2011)

5. R.B. Anderson, R. Giberson, Aboriginal entrepreneurship and economic development in Canada: thoughts on current theory and practice', in Stiles, C. and Galbraith, C. (Eds.): Ethnic Entrepreneurship: Structure and Process. (Elsevier Science, Amsterdam, 2004)

6. P. Fithri, A. F. Sari, Analisis Kompetensi Kewirausahaan Industri Kecil Suku Cadang di Kota Padang. Jurnal Optimasi Sistem Industri 11, 279-292 (2012)

7. J. Euchner, A. Ganguly, Business Model Innovation in Practice: A systematic approach to business model innovation can help capture value and reduce risks. Research Technology Management, 33-39 (2014)

8. E. Manik, D. P. Coenraad, Pengaruh fungsi kepemimpinan, kompetensi, dan budaya organisasi terhadap kinerja pegawai pada Direktorat Jenderal Energi Baru, Terbarukan dan Konservasi Energi. Jurnal Ekonomi, Bisnis, dan Entrepreneurship 9, 56-67 (2015)

9. J. B. Barney, Firm Resources and Sustained Competitive Advantage. Journal of Management 17, 99-120 (1991)

10. F. R. David, Manajemen Strategis: Konsep. (Edisi Bahasa Indonesia, Prenhallindo, Jakarta, 2002)

11. D. I. E. Sundah, C. Langi, D. R. S. Maramis, Developing entrepreneurial competencies for successful business model canvas. Journal of Physics: Conference Series 953, 012-040 (2018)

12. M. Hitka, S. Lorincova, M. Gejdos, K. Klaric, D. Weberova, Management Approach of White-collar Employees in Forest Enterprises. BioResources 14, 5488-5505 (2019)

13. V. Farkasova, L. Lizbetinova, Kariera ako sucast rozvoja osobnosti. (EDIS, Zilina, 2016)

14. G. Boak, S. Crabbe, Evaluating the impact of coaching skills training on individual and corporate behaviour. European journal of training and development 43, 153-165 (2019)

15. M. Krajcovic, V. Hancinsky, L. Dulina, P. Grznar, M. Gaso, J. Vaculik, Parameter setting for a genetic algorithm layout planner as a toll of sustainable manufacturing. Sustainability 11, 1-2 (2019)

16. M. Buckova, M. Krajcovic, M. Edl, Computer simulation and optimization of transport distances of order picking processes. Procedia Engineering 192, 69-74 (2017)

17. P. Bubenik, F. Horak, Knowledge-based systems to support production planning. Technicki vjesnik Technical gazette 21, 505-509 (2014)

18. M. Tazky, M., M. Rakyta, Increasing the effectiveness of service activities. Management. Journal of contemporary management issues 11, 1-7 (2006)

19. S. Olejarova, J. Dobransky, J. Svetlik, M. Pituk, Measurements and evaluation of measurements of vibrations in steel milling process. Measurement: Journal of the International Measurement Confederation 106, 18-25 (2017)

20. J. Soviar, M. Holubcik, J. Vodak, M. Rechtorik, F. Polak, The presentation of automotive brands in the on-line environment the perspective of KIA, Peugeot, Toyota and VW in the Slovak Republic. Sustainability 11, 1-21 (2019) 